\title{
Generiek of specifiek opleiden?
}

Citation for published version (APA):

van der Velden, R. K. W. (2011). Generiek of specifiek opleiden? Tijdschrift voor Arbeidsvraagstukken, 27(3), 382-397.

Document status and date:

Published: 01/01/2011

Document Version:

Publisher's PDF, also known as Version of record

\section{Please check the document version of this publication:}

- A submitted manuscript is the version of the article upon submission and before peer-review. There can be important differences between the submitted version and the official published version of record.

People interested in the research are advised to contact the author for the final version of the publication, or visit the DOI to the publisher's website.

- The final author version and the galley proof are versions of the publication after peer review.

- The final published version features the final layout of the paper including the volume, issue and page numbers.

Link to publication

\footnotetext{
General rights rights.

- You may freely distribute the URL identifying the publication in the public portal. please follow below link for the End User Agreement:

www.umlib.nl/taverne-license

Take down policy

If you believe that this document breaches copyright please contact us at:

repository@maastrichtuniversity.nl

providing details and we will investigate your claim.
}

Copyright and moral rights for the publications made accessible in the public portal are retained by the authors and/or other copyright owners and it is a condition of accessing publications that users recognise and abide by the legal requirements associated with these

- Users may download and print one copy of any publication from the public portal for the purpose of private study or research.

- You may not further distribute the material or use it for any profit-making activity or commercial gain

If the publication is distributed under the terms of Article $25 \mathrm{fa}$ of the Dutch Copyright Act, indicated by the "Taverne" license above, 


\title{
ARTIKELEN
}

\section{Generiek of specifiek opleiden?*}

\author{
Rolf van der Velden ${ }^{* *}$
}

De kennissamenleving stelt hoge eisen aan het onderwijs, maar over de wijze waarop het onderwijs moet worden ingericht bestaan tegenstrijdige opvattingen. Volgens sommigen is het belangrijk dat het onderwijs beter aansluit bij de behoeften vanuit de arbeidsmarkt en dat studenten meer specifieke competenties verwerven om succesvol te kunnen opereren op de arbeidsmarkt. Anderen geven juist aan dat vakspecifieke competenties snel aan veroudering onderhevig zijn en dat het daarom van belang is dat studenten vooral generieke competenties verwerven.Dit artikel geeft een overzicht van de inzichten over de verwerving van generieke en specifieke competenties in het onderwijs, de effecten van deze competenties op de arbeidsmarktintrede en de latere loopbaan en de conclusies die men hieraan kan verbinden over de gewenste inrichting van het onderwijs.

\section{Inleiding}

De kennissamenleving stelt hoge eisen aan het onderwijs. Bij de formulering van de zogeheten Lissabon-doelstellingen is aan het onderwijs een sleutelrol toebedacht om Europa tot de meest innovatieve en competitieve economie van de wereld te maken. Het onderwijsbeleid is er daarom op gericht om de deelname aan middelbaar en hoger onderwijs te verhogen en voortijdig schoolverlaten te verminderen. Over deze doelstelling bestaat een brede consensus (voor afwijkende geluiden, zie bijvoorbeeld de prikkelende publicatie van Wolf, 2002). Over de wijze waarop het onderwijs vervolgens moet worden ingericht bestaan echter tegenstrijdige opvattingen. Grofweg zijn er twee kampen die men gemakshalve zou kunnen aanduiden als de Specifieken en de Generieken. Volgens de Specifieken is het belangrijk dat het onderwijs beter aansluit bij de behoeften vanuit de arbeidsmarkt. Vaak wordt dit vertaald in een roep om meer beroeps- en praktijkgeoriënteerd op te leiden en om binnen het onderwijs sneller te reageren op de gewijzigde vraag vanuit de arbeidsmarkt. In deze visie moet het onderwijs dus specifieker en responsiever worden.

Volgens de Generieken is de precieze vraag vanuit de arbeidsmarkt niet goed te voorspellen. Door de snelle technologische ontwikkelingen zouden vakspecifieke

* Dit artikel is gebaseerd op een rede uitgesproken bij de aanvaarding van het ambt van bijzonder hoogleraar Onderwijs en Beroepsloopbaan aan de Faculteit der Economische Wetenschappen en Bedrijfskunde van de Universiteit Maastricht op vrijdag 2 juni 2006.

** Rolf van der Velden is hoogleraar aan de Universiteit Maastricht en werkzaam bij het Researchcentrum voor Onderwijs en Arbeidsmarkt (ROA). Correspondentie: r.vandervelden@ maastrichtuniversity.nl 
competenties sneller aan veroudering onderhevig zijn dan generieke, zouden grenzen tussen beroepen en disciplines vervagen en zou het daarom beter zijn om studenten duurzame kerncompetenties bij te brengen die ze in een brede range van contexten kunnen toepassen. In deze visie moet het onderwijs juist generieker en breder worden. Leerlingen en studenten moeten vooral 'leren leren', ze moeten leren om probleemoplossend te handelen en ze moeten een reeks van sociale vaardigheden ontwikkelen.

De tegenstelling tussen beide opvattingen draagt kenmerken in zich van een diepe geloofstwist, zoals die tussen de Arminianen en de Gomaristen over de juiste interpretatie van de calvinistische leer. En net als bij een geloofstwist zijn de aanhangers van beide richtingen niet erg geneigd om zich op basis van wetenschappelijke of empirische argumenten te laten overtuigen. De strijd wordt bovendien op alle niveaus van het onderwijs gevoerd: of het nu gaat om de discussie rond de basisvorming in het vmbo, de discussie rond het Studiehuis in havo en vwo, de discussie rond de vorming van brede multi- en interdisciplinaire studierichtingen in het hoger onderwijs of de recente beleidswens van minister van Bijsterveldt om de kernvakken (Nederlands, wiskunde, science) in het voortgezet onderwijs te versterken, het heeft allemaal te maken met een verschil van inzicht over de gewenste competenties en hoe je die het best kunt bijbrengen.

De strijd tussen de Specifieken en de Generieken gaat ook op en neer. Een aantal decennia geleden werd door werkgevers nog een vurig pleidooi gehouden voor een versterking van het beroepsonderwijs (bijvoorbeeld Adviescommissie inzake het industriebeleid, 1981) - wie herinnert zich niet de verzuchting uit die tijd: 'Ach meneer, ze kunnen tegenwoordig geen hamer meer vasthouden.' Tegenwoordig echter lijken de Generieken aan de winnende hand. Met enige regelmaat worden lijsten gepubliceerd van zogeheten kerncompetenties ('key skills') waarover afgestudeerden zouden moeten beschikken om met succes de arbeidsmarkt te kunnen betreden. De volgende lijst is ontleend aan de Britse Qualification and Curriculum Authority (QCA, 2006). Zij onderscheiden de volgende kerncompetenties:

1. Rekenvaardigheden;

2. Communicatieve vaardigheden;

3. Leervaardigheden;

4. ICT-vaardigheden;

5. Probleemoplossende vaardigheden;

6. Samenwerking met anderen.

Meer recent heeft deze discussie een nieuwe impuls gekregen door de vraag naar welke kennis en vaardigheden nodig zijn voor de moderne kenniseconomie, de zogeheten '21st Century Skills'. Voogt en Pareja Roblin (2010) komen na een literatuurstudie tot een vrijwel identieke lijst, namelijk samenwerking, communicatie, ICT geletterdheid, sociale en/of culturele vaardigheden (inclusief burgerschap), creativiteit, kritisch denken en probleemoplossingsvaardigheden. Er verschijnen veel van dit soort lijsten en ze kennen een hoge mate van overlap (Salganik \& Stevens, 2003; Trier, 2003). Opvallend is echter dat vakspecifieke competenties meestal ontbreken.

Van beide opvattingen kan men stellen dat ze een te simpele voorstelling van zaken geven en er bestaat niet zoiets als de Dordtse Synode waarmee het pleit 
tussen de Generieken en de Specifieken beslecht kan worden. In dit artikel zal een aantal inzichten gepresenteerd worden uit de sociologie, de psychologie en de economie, waarmee licht geworpen wordt op de vraag hoe competenties verworven worden en wat de effecten zijn op de arbeidsmarkt. Toegespitst op het centrale thema: 'generiek of specifiek opleiden?' komen de volgende vragen aan de orde:

1. Wat is bekend over de verwerving van generieke en specifieke competenties in het onderwijs?

2. Wat is bekend over de effecten van generieke en specifieke competenties op de arbeidsmarktintrede en de latere loopbaan?

3. Welke conclusies kan men hieraan verbinden over de inrichting van het onderwijs?

Generieke competenties worden gedefinieerd als competenties die in een brede range van contexten kunnen worden toegepast en specifieke competenties als competenties die slechts in een beperkt aantal contexten kunnen worden toegepast. Op vergelijkbare wijze wordt het verschil tussen generieke en specifieke opleidingen gedefinieerd: generieke opleidingen zijn opleidingen die op een breed beroependomein voorbereiden en specifieke opleidingen bereiden slechts op één of enkele beroepen voor.

Dit artikel gaat eerst in op de verwerving van generieke en specifieke competenties in het onderwijs. Vervolgens komen de effecten van generieke en specifieke competenties op de arbeidsmarktintrede aan bod. Wij sluiten af met conclusies en implicaties voor het beleid.

\section{Verwerving van generieke en specifieke competenties in het onderwijs?}

Los van de vraag of de arbeidsmarkt nu specifiek of generiek opgeleide mensen vereist, is het belangrijk om stil te staan bij de vraag hoe competenties verworven worden. Dit geeft immers het speelveld aan waarbinnen curriculumontwerpers zich kunnen bewegen. Daarbij spelen de volgende drie aspecten een rol:

1. Welke inzichten kunnen ontleend worden aan de wijze waarop expertise ontwikkeld wordt?

2. Is er sprake van een afruil tussen het ontwikkelen van specifieke en generieke competenties?

3. Wat is de relatie tussen inrichting van de leeromgeving en wijze van toetsen enerzijds en competentieontwikkeling anderzijds?

\section{Inzichten over de ontwikkeling van expertise}

In de inleiding is gerefereerd aan het pleidooi van de Generieken voor de zogenaamde kerncompetenties. Het is niet vreemd dat een dergelijk pleidooi is ontstaan. Vanuit het perspectief van het onderwijs is het een aantrekkelijke gedachte om je te kunnen richten op duurzame generieke competenties waarmee de lerende zelf de meer specifieke competenties kan verwerven. In plaats van een omvangrijk programma waarin een grote hoeveelheid specifieke competenties 
moet worden bijgebracht, kan men dan volstaan met het leren van een beperkte set van kerncompetenties. De vraag is echter of dit ook gedragen wordt door de inzichten vanuit de cognitieve psychologie.

Hoewel het proces waarlangs mensen leren, kennis en vaardigheden verwerven en toepassen, nog steeds voor een belangrijk deel een 'black box' is, is onder cognitief psychologen en onderwijskundigen een brede consensus ontstaan over het belang van contexten bij het proces van informatieverwerking. Het menselijke brein is geen 'tabula rasa' waar informatie in elke mogelijke vorm kan worden opgeslagen (Schmidt, 1997). Informatie krijgt pas betekenis wanneer ze in een contextueel raamwerk past en nieuwe informatie wordt beter verwerkt wanneer ze gerelateerd kan worden aan eerdere informatie. Ook het terughalen van informatie is contextgebonden.

Sommige onderzoekers betwijfelen zelfs of er zoiets als generieke competenties bestaan en beargumenteren dat ook generieke competenties contextgebonden zijn (Perkins \& Salomon, 1989). Of men zover moet gaan is de vraag, maar men maakt wel terecht een punt dat generieke competenties los van een specifieke context betrekkelijk weinig nut hebben. De Duitse psycholoog Weinert verwoordde het aldus: 'Over the last decades, the cognitive sciences have convincingly demonstrated that context-specific skills and knowledge play a crucial role in solving difficult tasks. Generally, key competencies cannot adequately compensate for a lack of content-specific competencies' (Weinert, 2001: 53).

Generieke competenties krijgen dus pas betekenis wanneer ze in een specifieke context worden toegepast en kunnen een gebrek aan specifieke competenties niet compenseren. Het is een van de kritiekpunten die naar voren is gekomen op het Studiehuis. De psycholoog Schmidt zei hierover in een interview: 'Al sinds de jaren zeventig is er een groep onderwijskundigen die de grotendeels onjuiste gedachte uitdraagt dat kennis snel veroudert... Voor deze groep was het vooral belangrijk dat leerlingen zelfstandig kennis leerden zoeken. Maar wat stelt dit nou voor: met Google internet afstruinen? Het kan nooit de bedoeling zijn geweest het verwerven van kennis te vervangen door zoekvaardigheden... Goed zoeken van kennis vergt juist kennis van het domein' (Schmidt, 2006).

Niet alleen krijgen generieke competenties pas betekenis wanneer ze in een specifieke context worden toegepast, het is ook de vraag of ze gescheiden ontwikkeld kunnen worden. Enerzijds is het evident dat bepaalde basiscompetenties, zoals rekenvaardigheid en taalvaardigheid een noodzakelijke voorwaarde vormen om andere meer specifieke competenties te kunnen verwerven. Het is niet goed denkbaar dat iemand een goede automonteur of verpleegkundige kan worden zonder elementaire kennis van taal of rekenen. Anderzijds worden 'hogere' generieke competenties zoals probleemoplossende vaardigheden of analytische vaardigheden juist ontwikkeld als bijproduct van een meer specifieke scholing. De ontwikkeling van academische vaardigheden zoals analytische vermogens en kritische reflectie vergt een intensieve scholing in een bepaalde discipline of vakgebied. Het is in de praktijk dan ook niet goed mogelijk gebleken om dergelijke algemene competenties in aparte 'vakken' te onderwijzen (Weinert, 2001).

Dit is ook in lijn met hoe gewoonlijk het competentiebegrip wordt opgevat. In het internationale project Definition and Selection of Competencies (DeSeCo) wordt 
dit gedefinieerd als: 'the ability to successfully meet complex demands in a particular context through the mobilization of psychosocial prerequisites (including both cognitive and non-cognitive aspects)' (Rychen \& Salganik, 2003: 43). Deze definitie benadrukt het holistische karakter van competenties: iemand is pas competent wanneer hij of zij over de verschillende kenniselementen, vaardigheden en houdingen beschikt om bepaalde handelingen te kunnen verrichten, en ook in staat is om deze op de juiste wijze te orkestreren en in gezamenlijkheid toe te passen. In die zin vormt het geheel van een competentie meer dan de som der delen van de afzonderlijke kennis-, vaardigheids- en houdingselementen (Allen \& Van der Velden, 2005).

\section{Afruil tussen het ontwikkelen van specifieke en generieke competenties?}

In de onderwijseconomische literatuur wordt niettemin vaak aangenomen dat er wel een afruil is tussen het aanleren van generieke competenties en het bijbrengen van specifieke competenties. De redenering is als volgt. Leeruitkomsten worden in belangrijke mate bepaald door de hoeveelheid instructietijd, de zogeheten 'time on task' (Gamoran \& Dreeben, 1986). Omdat de hoeveelheid tijd binnen een curriculum per definitie begrensd is, betekent dit dat aandacht besteden aan het een per definitie ten koste gaat van aandacht aan het ander. Zo ook zullen curriculumontwerpers binnen een opleiding een balans moeten vinden tussen het bijbrengen van generieke competenties en het bijbrengen van specifieke competenties.

De vraag is of dit klopt. Zoals eerder aangegeven is het moeilijk om de ontwikkeling van generieke en specifieke competenties te scheiden. Het is in dit verband interessant om eens te kijken naar de mate waarin landen verschillen in het bijbrengen van generieke en specifieke competenties (OECD, 2005). In figuur 1 staan op de X-as de gemiddelde testscores op de zogeheten PISA-survey uit 2005. Dat is een grootschalig internationaal onderzoek dat onder auspiciën van de OECD wordt gehouden naar de schoolprestaties van 15-jarigen. Vermeld staan de gemiddelde scores van een land op de domeinen wiskunde en probleem oplossen en men kan dit beschouwen als een indicator van de generieke competenties die ontwikkeld worden. Op de Y-as staat als proxy voor de mate waarin in een onderwijssysteem specifieke competenties worden ontwikkeld het percentage studenten dat binnen het voortgezet onderwijs een beroepsgerichte opleiding volgt. Wanneer er sprake zou zijn van een afruil tussen de verwerving van generieke competenties enerzijds en specifieke competenties anderzijds zou men een negatief verband verwachten tussen deze beide indicatoren. Dat is echter niet het geval en het verband is eerder zwak positief.

Het feit dat op het niveau van landen geen afruil bestaat tussen de verwerving van generieke en specifieke competenties hoeft nog niet te betekenen dat dit op individueel niveau ook het geval is. Het is daarom ook van belang om op individueel niveau naar de verwerving van generieke en specifieke competenties te kijken. In een grootschalig internationaal onderzoek onder hoger opgeleiden, de zogeheten CHEERS-survey, is informatie verzameld over de competenties die men ver- 
Figuur 1: De relatie tussen generieke en specifieke competenties in 19 OECDlanden

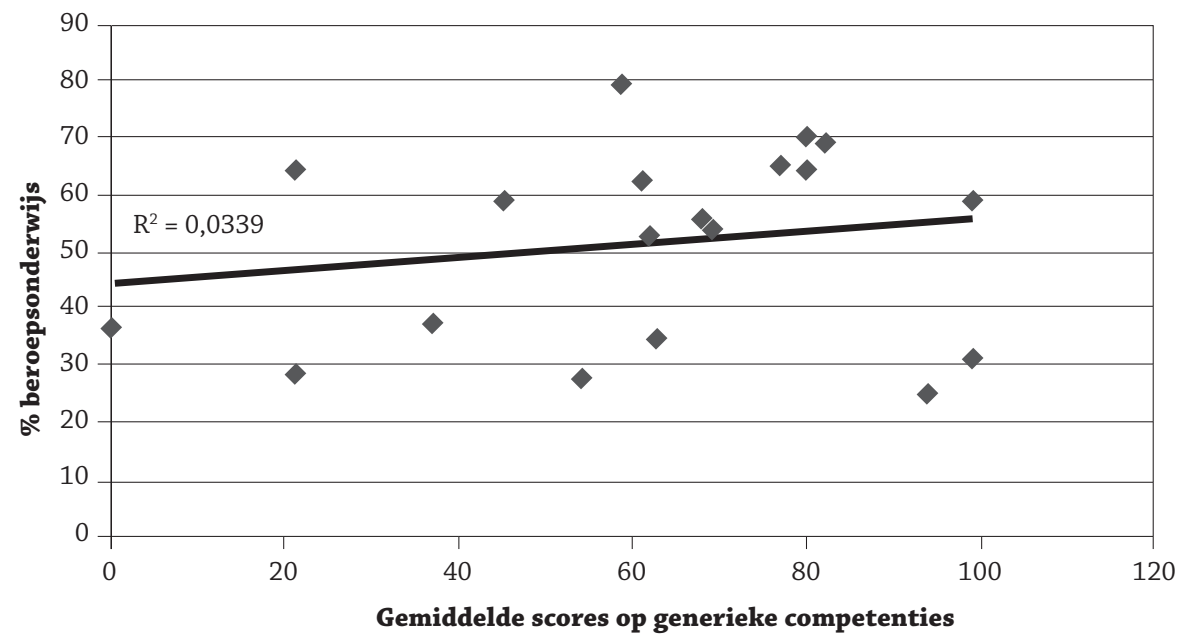

Bron: OECD (2005).

worven heeft in het hoger onderwijs. Sommige daarvan hebben betrekking op generieke academische competenties, zoals analytische vaardigheden of probleem oplossen, andere hebben betrekking op vakspecifieke competenties. Hoewel in het onderzoek beide typen competenties als aparte clusters naar voren komen (Meng, 2006), is de correlatie tussen de scores op academische competenties enerzijds en de vakspecifieke competenties anderzijds positief, en bedraagt deze zelfs 0,35 .

Met andere woorden van een duidelijke afruil is geen sprake of anders geformuleerd: het bijbrengen van beroepsspecifieke competenties hoeft niet ten koste te gaan van het bijbrengen van meer generieke competenties. Dat wil natuurlijk niet zeggen dat er helemaal geen afruil is, maar die heeft wellicht meer betrekking op de scholing in specifieke competenties dan op de scholing in generieke competenties. Wie tijd besteedt aan het maken van biologieopgaven, kan die tijd niet besteden aan het vertalen van Latijnse teksten. Maar in beide gevallen oefen je wel je analytische vermogens.

Dat neemt niet weg dat een scholing in specifieke competenties niet automatisch betekent dat tegelijkertijd ook generieke competenties ontwikkeld worden. Gelet op de lage correlaties die hierboven gevonden zijn is er blijkbaar binnen specifieke opleidingen nog een grote variatie in de mate waarin ook generieke competenties worden bijgebracht. Dit brengt ons bij het vraagstuk van de inrichting van de leeromgeving en de wijze van toetsen.

\section{Leeromgeving, wijze van toetsen en competentieontwikkeling}

In deze paragraaf komt de relatie aan bod tussen de inrichting van de leeromgeving en de wijze van toetsen enerzijds en competentieontwikkeling anderzijds. De laatste jaren is een aantal studies verschenen waarin de relatie wordt bestudeerd 
Tabel 1: $\quad$ Effecten van leeromgeving op de verwerving van generieke en specifieke competenties

\begin{tabular}{lll}
\hline Leeromgeving & $\begin{array}{l}\text { Generieke } \\
\text { competenties }\end{array}$ & $\begin{array}{l}\text { Specifieke } \\
\text { competenties }\end{array}$ \\
\hline Traditioneel zonder actieve docent (referentie) & 0 & 0 \\
Traditioneel met actieve docent & 0 & + \\
Activerend zonder actieve docent & + & 0 \\
Activerend met actieve docent & + & + \\
\hline
\end{tabular}

Bron: Meng (2006).

tussen curriculumkenmerken enerzijds en de ontwikkeling van competenties anderzijds. Zo hebben Vaatstra en De Vries laten zien dat activerende leeromgevingen een positief effect hebben op de ontwikkeling van generieke competenties, zoals zelfstandigheid en samenwerken, maar niet op de verwerving van vakkennis (Vaatstra \& De Vries, 2007). Meng (2006) onderscheidt op basis van de eerdergenoemde CHEERS-survey twee dimensies in de leeromgeving. Aan afgestudeerden is gevraagd om een karakterisering te geven van de wijze waarop onderwijs werd gegeven. Twee vragen hadden betrekking op de mate waarin sprake is van gebruik van activerende leermethoden zoals projectonderwijs of probleemgestuurd onderwijs en de mate waarin de docent een actieve rol speelt in de kennisoverdracht. Op basis van de antwoorden op deze twee vragen onderscheidt hij vier typen leeromgevingen. Leeromgevingen waarbij activerende leermethoden niet of nauwelijks werden gebruikt zijn getypeerd als traditioneel. Als ze wel werden gebruikt werden ze getypeerd als activerend. Evenzo werden leeromgevingen getypeerd naar de mate waarin de docent een actieve rol speelt. De combinatie van beide variabelen levert vier soorten leeromgevingen op. Vervolgens is hij nagegaan in welke leeromgeving de afgestudeerden de meeste generieke en specifieke competenties hebben verworven (zie tabel 1).

De verwerving van competenties is het laagst in 'LOI-achtige' leeromgevingen: traditionele leermethoden met veel nadruk op zelfstudie. De hoogste verwerving van zowel generieke als specifieke competenties vindt plaats in de omgeving die gekenmerkt wordt door activerende leermethoden én een actieve rol van de docent. De rol van activerende leermethoden blijkt vooral de verwerving van generieke competenties te bevorderen, terwijl het effect van een actieve docent vooral zit in het bevorderen van vakspecifieke competenties. Daarnaast laat hij zien dat - in lijn met de theorie over 'Time on Task' - instructietijd een positief effect heeft op de ontwikkeling van specifieke competenties, terwijl tijd besteed aan zelfstudie en stages een positief effect heeft op zowel de verwerving van generieke als specifieke competenties (Meng, 2006).

Dit spoort natuurlijk met wat hierover theoretisch verwacht mag worden. Activerende leermethoden zijn immers vooral ontwikkeld om generieke competenties te bevorderen, zoals multidisciplinaire kennis, 'leren leren', probleemoplossend han- 
delen en samenwerken (Barrows, 1996), terwijl de rol van een docent a priori geassocieerd wordt met die van een professionele expert die vakspecifieke kennis overdraagt in een meester-gezel relatie.

De conclusie die men hieruit kan trekken is dat men ook binnen specifieke opleidingen heel goed generieke competenties kan bijbrengen door bepaalde onderwijsmethoden toe te passen. Dat geldt overigens niet alleen voor de onderwijsmethode, maar ook voor de wijze van toetsen en examineren. Het naïeve traditionele beeld dat mensen hebben over leren is dat van een simpele overdracht van kennis van een leraar aan een student. Een student volgt een hoorcollege of een werkgroep. De docent brengt informatie over en na het college of de werkgroep is de student in staat om de verworven kennis in uiteenlopende situaties toe te passen. In de praktijk echter gaat het er vaak anders aan toe. In zijn inaugurale rede gebruikt Van der Vleuten het beeld van de calculerende student die uitsluitend die dingen leert die hem of haar helpen om het examen te halen. Vlak voor het tentamen wordt de leerstof grondig geoefend, maar direct daarna wordt de geestelijke harde schijf weer gewist om plaats te maken voor de leerstof van het volgende tentamen (Van der Vleuten, 1996). Zijn conclusie is dat het leergedrag van studenten in belangrijke mate wordt gestuurd door de wijze waarop getoetst en geëxamineerd wordt. Curriculumontwerpers moeten er dus niet alleen voor zorgen dat de onderwijsmethode in overeenstemming is met de leerdoelen ('teach as you preach'), maar ook dat de wijze van toetsen daarop is afgestemd. Immers: 'assessment drives learning'. Een recent onderzoek onder afgestudeerden uit het hoger onderwijs, de REFLEX-studie, laat zien dat examinering en toetsing van studenten via essays en presentaties veel effectiever is voor de verwerving van generieke competenties dan examinering en toetsing via multiplechoice-examens (Allen \& Van der Velden, 2011).

\section{Effecten van generieke en specifieke competenties op de arbeidsmarktintrede}

In deze paragraaf komt de vraag aan de orde wat de effecten zijn van generieke en specifieke competenties op de arbeidsmarktintrede. De volgende vragen worden behandeld:

1. Wat zegt de theorie?

2. Vindt men hiervoor ook bewijzen in de empirie?

3. Zijn generieke competenties in de loop van de tijd belangrijker geworden?

4. Hoe zit het met de effecten op langere termijn?

5. Waarom is het soms moeilijk om goede empirische bewijzen te vinden?

\section{Wat zegt de theorie?}

In de theorie van het menselijk kapitaal wordt het volgen van onderwijs beschouwd als een investering die de productieve vermogens vergroot en daarmee leidt tot een hogere beloning op de arbeidsmarkt (Becker, 1964). Hoe meer competenties iemand heeft, hoe productiever hij of zij is. Een belangrijke modificatie van deze theorie is dat deze competenties natuurlijk alleen beloond worden wanneer er een expliciete vraag naar is. Theoretisch mag verwacht worden dat afge- 
studeerden die meer specifiek zijn opgeleid voor een bepaald beroep een hogere productiviteit in dat beroep zullen bereiken dan afgestudeerden die voor een breder domein zijn opgeleid (De Grip \& Heijke, 1991). De laatstgenoemde groep zal aanvullende training op de werkplaats nodig hebben om te kunnen voldoen aan de eisen die het beroep stelt. Daar staat tegenover dat de specifiek opgeleiden sterker afhankelijk zijn van de vraag naar arbeid in hun eigen domein. Bij een tekortschietende vraag moeten zij uitwijken naar andere domeinen waar ze geen comparatief voordeel kunnen behalen met hun specifieke competenties. Er is dus een afruil in de opbrengsten van generieke en specifieke competenties: de specifieke competenties verhogen de inzetbaarheid voor een specifiek domein, terwijl de generieke competenties de flexibiliteit bevorderen.

\section{Vindt men hiervoor ook bewijzen in de empirie?}

Er zijn duidelijke aanwijzingen dat afgestudeerden van generieke opleidingen inderdaad meer training nodig hebben in de initiële transitiefase dan afgestudeerden van meer specifieke opleidingen (Van Smoorenburg \& Van der Velden, 2000). De empirische resultaten over de productiviteitseffecten van specifieke opleidingen zijn echter wat gemengd. Een aantal studies wijst uit dat er een duidelijk positief effect is van de beroepsgerichtheid van een opleiding op het succes van de arbeidsmarktintrede (Bishop, 1994; Arum \& Shavit, 1995). Zo laat de Amerikaanse econoom Bishop (1994) in een overzichtsstudie zien dat specifieke beroepscompetenties betere voorspellers zijn van de prestaties in een beroep dan cognitieve vermogens of andere generieke competenties en dat deze ook beter beloond worden. Ook een aantal internationale studies wijst op het belang van versterking van beroepsonderwijs voor een succesvolle overgang van onderwijs naar arbeidsmarkt (Müller \& Shavit, 1998; OECD, 2000). En Allen en Van der velden (2011) laten zien dat vakspecifieke competenties de belangrijkste voorspeller zijn van arbeidsmarktsucces voor afgestudeerden.

Maar zoals aangegeven, de bewijzen zijn wat gemengd. Zo komt Ryan in zijn overzichtsstudie tot de conclusie dat de empirische evidentie voor positieve effecten van de beroepsgerichtheid van een opleiding betrekkelijk gering zijn (Ryan, 2001). Wel vindt hij duidelijk positieve effecten wanneer leerlingen een zogeheten duale opleiding doorlopen hebben, dat zijn opleidingen waarbij leren en werken wordt gecombineerd, zoals in het leerlingwezen. Deze bevindingen zijn in lijn met de resultaten van een analyse die Van der Velden en Wolbers (2003) hebben uitgevoerd op de Europese Labour Force Surveys. Die analyse laat zien dat verschillen tussen landen in de integratie van jongeren in het arbeidssysteem niet samenhangen met de beroepsgerichtheid van het onderwijssysteem, maar wel met de aanwezigheid van duale opleidingen. Duale opleidingen zoals het leerlingwezen zorgen voor een institutionele band tussen het onderwijs- en het arbeidssysteem. Hierdoor verloopt de transitie minder abrupt en hebben afgestudeerden meer mogelijkheden om geleidelijk te integreren in het arbeidssysteem. Het is dus meer dit institutionele aspect dan de beroepsgerichtheid zelf dat ervoor zorgt dat duale opleidingen succesvoller zijn. Ook in andere analyses uitgevoerd onder zowel Nederlandse als Britse schoolverlaters worden niet of nauwelijks effecten gevonden van de beroepsgerichtheid van een opleiding of de breedte van het cur- 
riculum op de arbeidsmarktkansen (Dolton \& Vignoles, 2002; Van der Velden \& Wolbers, 2007).

Semeijn (2005) komt zelfs tot de conclusie dat vooral generieke competenties van afgestudeerden bepalend zijn voor hun arbeidsmarktsucces en niet de vakspecifieke. Zij heeft gekeken naar het effect van specifieke competenties, zoals scores op domeinspecifieke toetsen, scriptieresultaten en het opdoen van relevante werkervaring tijdens de studie. En dit is vergeleken met de effecten van generieke competenties zoals leerstijlen, persoonlijkheidskenmerken of het hebben van bestuurservaring. Een opvallend en ook verrassend resultaat was dat zij niet of nauwelijks effecten heeft kunnen vinden van specifieke competenties op het arbeidsmarktsucces van afgestudeerden, zoals dat tot uitdrukking komt in de kans op werk, het verkrijgen van een academische baan of de beloning (Semeijn, 2005). Generieke competenties echter bleken wel vaak een effect te hebben op het succes van de arbeidsmarktintrede.

Een mogelijke verklaring voor deze verschillen in resultaten is dat Semeijn (2005) zich richt op de effecten van generieke en specifieke competenties voor afgestudeerden binnen een bepaalde opleiding. Dat impliceert dat de meeste afgestudeerden voor een belangrijk deel over dezelfde vakspecifieke competenties beschikken. Er is weliswaar nog verschillen, maar die wegen voor werkgevers blijkbaar minder sterk dan de verschillen in generieke competenties tussen deze afgestudeerden. Dat zou betekenen dat generieke competenties belangrijk zijn voor de verklaring van verschillen tussen afgestudeerden binnen een opleiding, terwijl specifieke competenties wellicht belangrijker zijn voor de verklaring van verschillen tussen opleidingen.

\section{Zijn generieke competenties in de loop van de tijd belangrijker geworden?}

Die vraag is niet met een eenvoudig ja of nee te beantwoorden. Door Levy en Murnane (2001) is gewezen op het feit dat de variantie in inkomens binnen opleidingsniveaus groter is geworden. Zij interpreteren dat als een indicatie dat andere competenties - lees: generieke competenties - belangrijker zijn geworden dan de competenties die men op school geleerd heeft - lees: de specifieke competenties. Maar het is ook heel goed mogelijk dat deze grotere variantie verklaard wordt door de toegenomen heterogeniteit van de opleidingspopulatie. Het onderwijs levert immers geen homogeen product af (Glebbeek, 1988): ook binnen een studierichting is er nog een wezenlijke variatie tussen de verschillende studenten. Met de groei van het hoger onderwijs, neemt die variatie natuurlijk ook toe, wat zich op de arbeidsmarkt zal vertalen in toegenomen verschillen in inkomen tussen afgestudeerden van een en het hetzelfde opleidingsniveau.

Een andere aanwijzing voor het feit dat generieke competenties belangrijker zouden zijn geworden is de vaak gehoorde bewering dat de opleidingsrichting steeds minder belangrijk zou worden. En dat het er meer om zou gaan dát je gestudeerd hebt en minder om wát je gestudeerd hebt. Het is goed om eens naar de feiten te kijken. Figuur 2 geeft het percentage afgestudeerden van het hbo en wo dat werkzaam is in een baan buiten de gevolgde opleidingsrichting. In de analyse zijn uitsluitend afgestudeerden opgenomen die een baan hebben waarvoor wel het eigen 
Figuur 2: $\quad$ Percentage afgestudeerden dat werkzaam is buiten de gevolgde opleidingsrichting

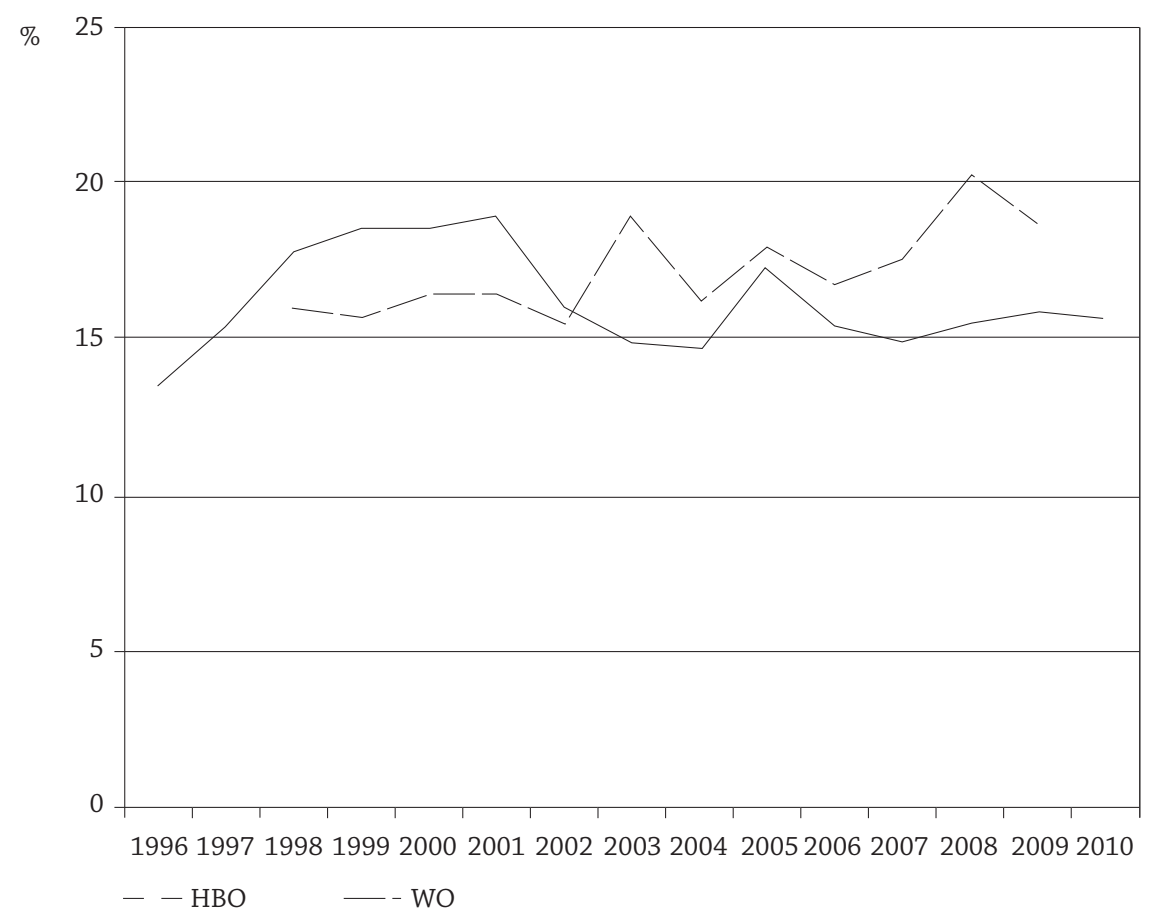

Bron: HBO- en WO-Monitor (1996-2010).

opleidingsniveau werd vereist, en de mensen die beneden hun niveau werkzaam zijn dus volledig buiten beschouwing gelaten.

De ontwikkeling bij het hbo lijkt eerst te wijzen op het minder belangrijk worden van specifieke opleidingseisen. Van degenen met een baan op hbo-niveau, was in 1996 ruim 13\% werkzaam in een functie waarvoor de eigen opleidingsrichting niet vereist werd en in 2000 bedroeg dit 19\%. Na 2000 echter neemt dit percentage weer af en stabiliseert het rond de $15 \%$. Hier is eerder sprake van een effect van het krapper worden van de arbeidsmarkt rond de eeuwwisseling dan van het daadwerkelijk veranderen van de selectie-eisen van werkgevers. Bij het wo ziet men eerst een nagenoeg constant percentage van $16 \%$ van afgestudeerden die werkzaam zijn in een functie buiten de eigen opleidingsrichting. Vanaf 2003 schommelt het tussen de $17 \%$ en $20 \%$, maar er is geen sprake van een duidelijke trend. Men kan concluderen dat het gevolgd hebben van een specifieke opleiding nog steeds een belangrijk selectiecriterium vormt bij de intrede in een bepaald beroepsdomein. 


\section{Hoe zit het met de effecten op langere termijn?}

Theoretisch kan men verwachten dat specifiek opgeleiden een groter risico lopen op competentieveroudering met bijbehorende gevolgen voor hun inzetbaarheid ('employability'). Daarnaast wordt veelal aangenomen dat generieke competenties een positief effect hebben op de verdere carrièremogelijkheden. In een eerdere analyse is voor de eerste hypothese weinig ondersteuning gevonden (Allen \& Van der Velden, 2002). De mate waarin kennis en vaardigheden van hoger opgeleiden verouderd waren, bleek uiteraard sterk samen te hangen met de vraag of men werkzaam was in domeinen die gekenmerkt werden door snelle technologische veranderingen, maar er is geen relatie gevonden met de mate waarin een opleiding generiek of juist specifiek is.

Over de langetermijneffecten van generieke competenties zijn verschillende studies verschenen. Een mooi voorbeeld is een Amerikaanse studie van Duncan en Dunifon (1998). Zij toonden aan dat jonge respondenten die volgens de interviewer in een opgeruimde kamer woonden 20 jaar later meer blijken te verdienen dan degenen die een slordige kamer hadden. De observatie van de interviewer wordt beschouwd als een proxy voor de mate waarin men ordelijk en gestructureerd is, en die factor bepaalt zowel het opruimen als het latere arbeidsmarktsucces. Meer recent zijn enkele studies verricht die het effect laten zien van het effect van generieke competenties, zoals testscores op Nederlands, rekenen en informatieverwerking en IQ, afgenomen op 12-jarige leeftijd op het arbeidsmarktsucces zo'n 20 jaar later (Traag et al., 2006; Büchner et al., 2009). Daarbij is gecontroleerd voor de effecten van de schoolloopbaan zelf en de effecten van de gezinskenmerken. De resultaten wijzen uit dat er nog effecten zijn - ook na controle voor de effecten die via de schoolloopbaan zelf verlopen - van schoolprestaties en schooladvies op twaalfjarige leeftijd op het succes in de latere loopbaan.

In beide voorbeelden ging het om studies die een effect laten zien van generieke competenties. Er zijn eigenlijk geen vergelijkbare studies te vinden over de langetermijneffecten van specifieke competenties en dat brengt ons ook bij de volgende vraag.

Waarom is het moeilijk om goede empirische bewijzen te vinden voor de rol van specifieke competenties?

In het voorafgaande is aangegeven dat er veel aanwijzingen zijn voor de effecten van generieke competenties, maar dat de bewijzen voor de effecten van de specificiteit van een opleiding of de rol van specifieke competenties gemengd zijn. Betekent dit nu dat generieke competenties inderdaad belangrijker zijn dan specifieke competenties? Zo simpel ligt dat niet. Er zijn twee belangrijke redenen waarom het belang van specifieke competenties stelselmatig wordt onderschat. De eerste reden is dat specifieke competenties in de regel slechter gemeten worden dan generieke competenties. Dit is inherent aan het concept van specifieke competenties. Om vast te kunnen stellen hoe goed iemand is in een specifiek kennisdomein, heb je toetsen nodig die per definitie tussen domeinen verschillen. Er bestaat niet zoiets als één meetlat waarmee men de vakspecifieke competenties van bijvoorbeeld een medicus kan vergelijken met die van een jurist. Juist vanwege die onvergelijkbaarheid ontbreken goede metingen van specifieke compe- 
tenties in algemene survey's (Murray, 2003). De nadruk komt daarmee eenzijdig te liggen op meer generieke competenties. Geen wonder dus dat men ook eerder effecten van generieke competenties zal vinden.

Een tweede reden heeft te maken met selectie-effecten. Opleidingen verschillen vooral van elkaar in de specifieke competenties die ze bijbrengen. Binnen een opleiding variëren studenten natuurlijk ook in het niveau van specifieke competenties die ze bereiken, maar die verschillen vallen in het niet wanneer deze vergeleken worden met mensen die de betreffende opleiding niet gevolgd hebben. Men kan het belang van specifieke competenties alleen maar goed vaststellen door de productiviteit van mensen die specifiek voor een bepaald beroep zijn opgeleid te vergelijken met de productiviteit van mensen die een heel andere opleiding hebben. Het probleem is echter dat mensen met een niet-passende opleiding vaak ook niet in dat specifieke domein terechtkomen. Niemand zal het in zijn hoofd halen om een econoom een openhartoperatie te laten uitvoeren of om een socioloog een brug te laten bouwen, hoe goed hun generieke competenties ook zijn. Specifieke competenties spelen daarmee een belangrijke rol om in het domein terecht te komen waarvoor men is opgeleid (Semeijn, 2005; Meng, 2006), maar men kan het belang van specifieke competenties niet altijd goed vaststellen. Het is een van de uitdagingen voor het toekomstige onderzoek om hiervoor goede oplossingen te bedenken.

Overigens wil dit niet zeggen dat als de zaken maar goed gemeten zijn, alle problemen ook voorbij zijn. Een mooi voorbeeld in dit verband heeft betrekking op het effect van computergebruik op beloning. In een gezaghebbende publicatie liet de Amerikaanse econoom Krueger (1993) zien dat het gebruik van een computer een positief effect had op de beloning en dit werd als een bewijs beschouwd van het belang van ICT-vaardigheden. Later echter hebben DiNardo en Pischke (1997) in een replicatie laten zien dat hetzelfde resultaat gevonden wordt voor het gebruik van potloden. $\mathrm{Zij}$ veronderstellen dat andere kenmerken van het individu (bijvoorbeeld IQ) zowel het computergebruik, het gebruik van pennen als de beloning bepalen. Borghans en Ter Weel (2004) komen echter met een alternatieve verklaring. Volgens hen is het niet zo dat ICT-vaardigheden op zichzelf de productiviteit verhogen, maar omgekeerd dat mensen die veel verdienen eerder een computer krijgen, omdat daar de efficiencyverbetering het grootst is. De boodschap is dus dat zelfs met goede meetinstrumenten men voorzichtig moet zijn met het trekken van de juiste conclusies.

\section{Implicaties en conclusies}

Dit artikel is gestart met een beschouwing over de strijd tussen de Generieken en de Specifieken over de gewenste inrichting van het onderwijs. Wat kan men leren van de hiervoor gepresenteerde bevindingen?

Ten eerste schuilt er een gevaar in de eenzijdige nadruk die door de Generieken wordt gelegd op de zogeheten kerncompetenties. In het voorafgaande is uitvoerig betoogd waarom bepaalde generieke competenties als probleem oplossen of kritisch denkvermogen niet goed ontwikkeld kunnen worden zonder het vehikel van 
een grondige disciplinaire of vakspecifieke scholing. Anders geformuleerd, het heeft weinig zin om een apart vak 'probleem oplossen' of 'kritische reflectie' in het curriculum op te nemen. Overigens wil het feit dat bepaalde competenties belangrijk gevonden worden niet altijd zeggen dat ze een plek moeten krijgen in het onderwijs. Van sommige competenties kan men zich afvragen óf ze wel in het initieel onderwijs ontwikkeld moeten worden of dat dit beter en effectiever later in de loopbaan kan plaatsvinden. Het onderwijs moet vooral een plek zijn waar je die dingen leert die je elders niet of met meer moeite leert. Voor veel zogenaamde generieke competenties geldt dat die evengoed of misschien zelfs wel beter buiten het onderwijs aangeleerd kunnen worden.

Ten tweede, het is evident dat de meest optimale kennisontwikkeling plaatsvindt in curricula die georganiseerd zijn rond goed gedefinieerde onderwerpen, en die een duidelijke cumulatieve opbouw van het programma kennen. Dit kan echter op gespannen voet staan met de wens van studenten om een eigen invulling aan het programma te geven. In de afgelopen jaren is er een tendens geweest op alle onderwijsniveaus om curricula meer modulair op te bouwen en flexibeler te maken. Dit kan echter ten koste gaan van de coherentie: een opleiding die het karakter heeft van een cafetariasysteem, waarbij elke student in vrijheid zijn eigen menu kan samenstellen, is niet de beste manier om op een bepaald terrein een grondige expertise op te bouwen.

Ten derde, de wijze van examineren en toetsen is net zo belangrijk als het curriculum zelf: 'assessment drives learning'. Toch lijkt het erop dat men zich drukker maakt over de relatie tussen leerdoelen en curricula dan over de vraag hoe er geselecteerd wordt. Niet alleen moet de wijze van selecteren meer in lijn gebracht worden met wat men wil bereiken, ook is het belangrijk om meer te weten te komen over de feitelijke selectieprocessen in de opleiding en de gevolgen hiervan op de arbeidsmarktloopbaan.

Ten vierde, zoals eerder aangegeven, vergroot specialisatie de productiviteit, maar vermindert het de flexibiliteit. Voor individuen houdt dit een risico in, zeker wanneer men opgeleid wordt voor een markt die conjunctuurgevoelig is, zoals het geval is voor veel technische beroepen. Bij toenemende onzekerheid op de arbeidsmarkt zullen studenten daarom eerder kiezen voor generieke opleidingen die meer uitwijkmogelijkheden bieden. Dit kan leiden tot een onderinvestering in specifieke opleidingen die een hoog risico hebben. Vanuit een macrostandpunt gezien is dit natuurlijk onwenselijk en is het belangrijk om dit marktfalen te compenseren (Booth \& Snower, 1995), bijvoorbeeld door tegemoetkomingen te verstrekken aan studenten die een opleiding volgen die een hoge waarde voor de samenleving vertegenwoordigt, maar ook een hoog risico voor henzelf inhoudt.

\section{Literatuur}

Adviescommissie inzake het industriebeleid (Commissie-Wagner) (1981). Een nieuw industrieel elan.

Allen, J. \& R. van der Velden (2002). When Do Skills Become Obsolete, and When Does It Matter? In: A. de Grip, J. van Loo \& K. Mayhew (red.), The Economics of Skills Obsoles- 
cence: Theoretical Innovations and Empirical Applications. Research in Labor Economics, Volume 21 (pp. 27-50). Oxford: Elsevier Science Ltd.

Allen, J. \& R. van der Velden (2005). The Role of Self-Assessment in Measuring Skills. REFLEX Working paper 2. Maastricht: ROA.

Allen, J. \& R. van der Velden (red.) (2011). The Flexible Professional in the Knowledge Society: New Challenges for Higher Education. Higher Education Dynamics, 35. Dordrecht: Springer.

Arum, R. \& Y. Shavit (1995). Secondary Vocational Education and the Transition from School to Work. Sociology of Education, 68, 187-204.

Barrows, H.S. (1996). Problem-Based Learning in Medicine and Beyond: A Brief Overview. New Directions for Teaching and Learning, 68, 1, 3-12.

Becker, G.S. (1964). Human Capital: A Theoretical and Empirical Analysis, with Special Reference to Education. New York: National Bureau of Economic Research.

Bishop (1994). Expertise and Excellence. Working Paper 95-13. Ithaca, NY: Cornell University.

Booth, A.L. \& D.J. Snower (1995). Acquiring Competencies, Market Failures, Their Symptoms and Policy Responses. Cambridge: Cambridge University Press.

Borghans, L. \& B. ter Weel (2004). Are Computer Skills the New Basic Skills? The Returns to Computer, Writing and Math Skills in Britain. Labour Economics, 11, 85-99.

Büchner, C., W. Smits \& R. van der Velden (2009). Education, Cognitive Skills and Labour Market Success: A Perspective on Gender Differences. Paper presented at the BHPS conference 9-11July, Essex.

DiNardo, J. \& J.S. Pischke (1997). The Returns to Computer Use Revisited: Have Pencils Changed the Wage Structure Too? Quarterly Journal of Economics, 112, 291-303.

Dolton, P.J. \& A. Vignoles (2002). Is a Broader Curriculum Better? Economics of Education Review, 21, 5, 415-429.

Duncan, G.J. \& Dunifon, R. (1998). "Soft-Skills" and Long-Run Labor Market Success. Institute for Policy Research, Northwestern University.

Gamoran, A. \& R. Dreeben (1986). Coupling and Control in Educational Organisations. Administrative Science Quarterly, 31, 612-632.

Glebbeek, A.C. (1988). De arbeidsmarktpositie van opleidingen: Ontwikkeling en illustratie van een theoretisch model. Tijdschrift voor Arbeidsvraagstukken, 4, 75-89.

Grip, A. de \& J.A.M. Heijke (1991). Flexibiliteit versus productiviteit. Onderzoek van onderwijs, 20, 6-8.

Krueger, A.B. (1993). How Computers Have Changed the Wage Structure: Evidence from Microdata, 1984-1989. Quarterly Journal of Economics, 108, 33-60.

Levy, F. \& R.J. Murnane (2001). Key Competencies Critical to Economic Success. In: D.S. Rychen \& L.H. Salganic (red.), Defining and Selecting Key Competencies (pp. 151-173). Göttingen: Hogrefe \& Huber.

Meng, C. (2006). Discipline-Specific or Academic? Acquisition, Role and Value of Higher Education Competencies. PhD thesis. Maastricht: ROA.

Müller, W. \& Y. Shavit (1998). The Institutional Embeddedness of the Stratification Process: A Comparative Study of Qualifications and Occupations in Thirteen Countries, In: Y. Shavit \& W. Müller (1998), From School to Work. A Comparative Study of Educational Qualifications and Occupational Destinations. Oxford: Clarendon Press.

Murray, T.S. (2003). Reflections on International Competence Assessments. In: D.S. Rychen \& L.H. Salganic (red.), Key Competencies for a Successful Life and a Well-functioning Society (pp. 135-159). Göttingen: Hogrefe \& Huber.

Organisation for Economic Co-operation and Development (2000). From Initial Education to Working Life: Making Transitions Work. Paris: OECD. 
Organisation for Economic Co-operation and Development (2005). Education at a Glance: OECD Indicators 2005. Paris: OECD.

Perkins, D.N. \& G. Salomon (1989). Are Cognitive Skills Context Bound? Educational Researcher, 18, 16-25.

Qualifications and Curriculum Authority (QCA, 2006): www.qca.org.uk/603.html.

Ryan, P. (2001). The School-to-Work Transition: A Cross-National Perspective. Journal of Economic Literature, 39, 34-92.

Rychen, D.S. \& L.H. Salganic (2003). A Holistic Model of Competence. In: D.S. Rychen \& L.H. Salganic (red.), Key Competencies for a Successful Life and a Well-functioning Society (pp. 41-62). Göttingen: Hogrefe \& Huber.

Salganic, L.H. \& M. Stephens (2003). Competence Priorities in Policy and Practice, In: D.S. Rychen \& L.H. Salganic (red.), Key Competencies for a Successful Life and a Well-functioning Society (pp. 13-40). Göttingen: Hogrefe \& Huber.

Schmidt, H.G. (1997). Drie factoren die verhinderen dat mensen zelfstandig leren kennis verwerven. Tijdschrift voor Hoger Onderwijs, 15, 26-33.

Schmidt, H.G. (2006). Interview in: De Ingenieur, 118, 24.

Semeijn, J. (2005). Academic Competences and Labour Market Entry: Studies Among Dutch Graduates. PhD thesis. Maastricht: ROA.

Smoorenburg, M.S.M. van \& R.K.W. van der Velden (2000). The Training of School-leavers: Complementarity or Substitution? Economics of Education Review, 19, 207-217.

Traag, T., J. van der Valk, R. van der Velden \& R. de Vries (2006). Dertigers op de arbeidsmarkt, ROA-R-2006/2. Maastricht: ROA + CBS.

Trier, U.P. (2003). Twelve Countries Contributing to DeSeCo: A Summary Report. In: D.S. Rychen, L.H. Salganic \& M.E. McLaughlin (Eds.), Selected Contributions to the $2^{\text {nd }}$ DeSeCo Symposium. Neuchâtel: Swiss Federal Statistics Office.

Vaatstra, R. \& R. de Vries (2007). The Effect of the Learning Environment on Competences and Training for the Workplace According to Graduates. Higher Education, 53, 335357.

Velden, R.K.W. van der \& M.H. J.Wolbers (2003). The Integration of Young People into the Labour Market: The Role of Training Systems and Labour Market Regulation. In: W. Mülller \& M. Gangl (red.), Transitions from Education to Work in Europe. The Integration of Youth into EU Labour Markets (pp. 186-211). Oxford: Oxford University Press.

Velden, R.K.W. van der \& M.H.J. Wolbers (2007), How Much Does Education Matter and Why? The Effects of Education on Socio-Economic Outcomes among School-Leavers in the Netherlands. European Sociological Review, 23, 65-80.

Vleuten, C.P.M. van der (1996). Beyond Intuition. Inaugural Lecture. Maastricht: Maastricht University.

Voogt, J. \& Pareja Roblin, N. (2010). 21 ${ }^{\text {st }}$ Century Skills: Discussienota. Enschede: Universiteit Twente.

Weinert, F.E. (2001). Concept of Competence: A Conceptual Clarification. In: D.S. Rychen \& L.H. Salganic (red.), Defining and Selecting Key Competencies (pp. 45-65). Göttingen: Hogrefe \& Huber.

Wolf, A. (2002). Does Education Matter? Myths about Productivity and Economic Growth. London: Penguin. 